\title{
A novel gel polymer electrolyte cell for in-situ application of corrosion electrochemical techniques
}

\author{
E. Cano*, A. Crespo, D. Lafuente, B. Ramirez Barat \\ Centro Nacional de Investigaciones Metalúrgicas (CENIM), Consejo Superior de Investigaciones \\ Científicas (CSIC). Avda. Gregorio del Amo 8, 28040 Madrid, Spain. \\ *Corresponding autor: ecano@cenim.csic.esPhone: +34 5538900
}

\begin{abstract}
Electrochemical techniques, such as electrochemical impedance spectroscopy (EIS), are widely used for corrosion studies. However, their applicability to studies on metallic cultural heritage has been less spread due to the usual need of performing measurements in-situ on sculptures or monuments. This paper presents the development of a gel polymer electrolyte (G-PE) cell to overcome the difficulties associated with the use of liquid electrolytes for in-situ measurements. $5 \%$ agar has been employed to gelify a $0.3 \mathrm{M} \mathrm{NaCl}$ electrolyte. Laboratory comparison has demonstrated that gelification with agar does not affect EIS results in a significant way. A robust and convenient electrochemical cell has been fabricated using this GPE and has been successfully applied to obtain EIS data from a bronze sculpture in the National Archaeological Museum in Madrid (Spain).
\end{abstract}

Keywords: EIS, cultural heritage, gel polymer electrolyte, corrosion

NOTICE: this is the author's version of a work that was accepted for publication in Electrochemistry Communications. Changes resulting from the publishing process, such as peer review, editing, corrections, structural formatting, and other quality control mechanisms may not be reflected in this document. Changes may have been made to this work since it was submitted for publication. A definitive version was subsequently published in Electrochem. Comm. Doi: 10.1016/j.elecom.2014.01.016.

http://dx.doi.org/10.1016/j.elecom.2014.01.016 


\section{Introduction}

Electrochemical methods have been extensively used in corrosion studies for many decades. Inthe metallic heritage field, they have been used for restoration purposes for a long time, but their use for evaluation of protection systems and patinas is much more recent and less popular [1].

A typical approach to study patinas and protective coatings for cultural heritage is to prepare artificial coupons that try to mimic the original composition of metallic artifacts, and to study them using traditional laboratory techniques, including EIS [2,3]. The main drawback of this approach is that the surface composition and properties of each artifact is unique and a patina that has been formed over centuries cannot be artificially reproduced. Other authors have applied electrochemical techniques to the characterization of real patinas scrapped from the monuments [4], what does not allow to evaluate their protective properties. EIS has also been applied to monitor stabilization treatments for archaeological objects $[5,6]$

Several authors have worked on the development of an electrochemical cell that allows in-situ measurements on real artifacts and monuments. The need for an electrolyte that should be kept in contact with the object and the counter and reference electrodes is one of the main difficulties for on-site electrochemical measurements. Letardi developed a "contact cell" in which the electrolyte was held in place by a cloth, which was kept moistened by addition of the electrolyte from a reservoir by capillarity [7-9]. This system allows a complete freedom in the election of the electrolyte to perform non-destructive EIS measurements, both in laboratory and monuments. However, it is still needed to handle a liquid electrolyte, and the flat surface of the contact probe is not suitable for curved or irregular surfaces. Angeliniet. al used commercial electrocardiogram electrodes to study patinas and protective coatings on monuments $[10,11]$. While this system is non-destructive and well suited for in-situ measurements, the low conductivity of the gel electrodes may be a limitation for the measurement of low impedance systems and causesinhomogeneities in the current distribution [12]. Additionally, EIS results obtained with this electrodes show significant differences with those obtained with conventional cells at low frequencies.

A common approach followed in many fields of electrochemistry where liquids electrolytes present disadvantages has been the use of polymer electrolytes (PE). PE can be defined as materials where a supramolecular system is doped with ions and present a significant conductivity [13]. These systemshave been extensively investigated and used in a wide variety of electrochemical devices, such as batteries (e.g. lead-acid batteries[14] or lithium batteries[15, 16]), electrochromic devices [17, 18], fuel cells[19], supercapacitors[20], sensors and actuators[21], an dye-sensitized solar cells [13,22].Several polymeric materials have been studied as PE, such as poly(ethylene oxide), polyacrlylates or polymethacrylates[15, 16] or silicates [14]. Natural polymers such as starch[23], chitosan[24], gelatin [25], pectin [26]or agar $[17,18]$ have been used as gel polymer electrolyte (G-PE). Those natural substances have the advantage of being innocuous to the people and the environment, biodegradable and usually inexpensive. Gelified electrolytes have also been used in corrosion studies, for instance, 
Newton and Sykes used a agar gel to immobilize alkaline chloride solutions, as analogues of pore solution in concrete [27]

In this communication, we present a novel design of an electrochemical cell based on a classical electrolyte used in corrosion research (in this case, an aqueous $\mathrm{NaCl}$ solution, but many other electrolytes can be used) gelified with agar to obtain a convenient cell for in-situ measurements.

\section{Materials and methods}

The design of the cell is based on a traditional 3 electrode cell: the working electrode (WE) is the object under study, the counter electrode (CE) is a stainless steel mesh and as reference electrode a silver wire electrochemically coated with $\mathrm{AgCl}$ has been used.

The main innovation of our design is the use of a G-PE made bygelification of the electrolyte ( $0.3 \mathrm{M} \mathrm{NaCl}$ solution in Mili-Q water, but other solutions can also be employed), using agar, as a convenient solution to overcome the difficulties of in-situ measurements in monuments and works of art. After the preparation of the electrolyte, $5 \% \mathrm{w} / \mathrm{v}$ of agar powder (technical grade) has been dispersed in the solution, heated until dissolution of the agar, allowed to cool down and casted on the electrochemical cell containing the RE and CE. The $5 \%$ concentration provided enough resistance for cell handling while keeping good flexibility to adapt to the surface to be measured.

EIS measurements have been carried out on bronze ( $5 \% \mathrm{Sn}$ ) coupons $(5 \times 5 \mathrm{~cm})$, polished using emery paper down to grade 1200 . EIS spectra have been acquired using a Gamry 600 Potentiostat, using a frequency swept from $100 \mathrm{kHz}$ to $10 \mathrm{mHz}, 10 \mathrm{mV}$ RMS amplitude (at the open circuit potential) and 10 points/decade. The area exposed to the electrolyte is $5.7 \mathrm{~cm}^{2}$. Analysis of the data has been carried out using GamryEchem Analyst software.

In order to validate the gelified electrolyte, a comparison has been made using a traditional flat-sample cell [1], using both the liquid (traditional) electrolyte and the G-PE, keeping all other geometrical parameters of the cell identical.

For in-situ measurements, the gel electrolyte was casted in a plastic mold having a $4 \mathrm{~mm}$ thickness outer ring that was removed after cooling of the solution, leaving a protruding gel electrolyte cylinder with a constant and known section $\left(5.7 \mathrm{~cm}^{2}\right)$. Figure 1 shows an image and a scheme of the cell. The applicability of this cell to real objects has been tested by doing EIS measurements on a bronze sculpture of the National Archaeological Museum of Madrid. The sculpture is one of the two large (aprox. $3.5 \times 1.8 \times 1.2 \mathrm{~m}$ ) "Sphinxes" made by Felipe Moratilla y Parretoin 1892 for the main entrance of the building. The surface of the bronze is covered by a thin non-uniform patina, result of many decades of exposure to the urban environment of Madrid.

\section{Results and discussion}

Figure 2 shows typical Bode (a) and Nyquist (c) plots of EIS spectra for polished bronze coupons using the liquid electrolyte and the G-PE. The validity of EIS data has been assessed by means of Kramers-Kronig transforms, obtaining a good correspondence between experimental and calculated values. The overall shape and features of the curves are similar. In order to 
evaluate the differences, data have been fitted to the equivalent electric circuit presented in the figure. This model has been previously proposed for EIS results obtained on patinated bronze $[28,29]$.In this circuit, $R_{\mathrm{e}}$ corresponds to the electrolyte resistance; the constant phase element $\left(\mathrm{CPE}_{1}\right)$ in parallel with another resistor $\left(R_{1}\right)$ can be attributed to the impedance of the patina(in our case, the thin cuprite layer that is immediately formed on copper upon exposure to air); $\mathrm{CPE}_{2}$ and $R_{2}$ model the double-layer capacitance and the charge transfer resistance respectively; and $\mathrm{CPE}_{3}$ and $R_{3}$ are attributedto Faradaic oxidation-reduction process that occur at the electrodesurface. The values for the different elements are presented in Table 1, and the results of the fitting are presented in Fig. 2, superimposed to experimental results. The validation of the equivalent circuit is out of the scope of this paper, and it is used here only as a tool to compare the different features of EIS curves in the different experimental conditions.

A minor change is observed in $\mathrm{R}_{\mathrm{e}}$ with the addition of agar. This change can be attributed to the interaction of the ions with the gel. Two different interactions can occur in the gel-waterelectrolyte systems, leading to opposite changes in the diffusion of the ions: on one hand, adsorption of ions on the gel and obstruction of their diffusion paths by the macromolecules decrease the diffusion coefficient in the medium; on the other hand, gel-water interactions increase the diffusivity of ions in the gelified electrolyte [30].This change in the diffusion of ions within the electrolyte would be responsible for the minor change in the electric conductivity of the electrolyte, $R_{\mathrm{e}}$. However, as opposed to commercial electrocardiography electrodes, our G-PE keeps the good conductivity of traditional liquid electrolytes [10-12].

The values of $C P E_{1}-R_{1}, C P E_{2}-R_{2}$ andCPE $-R_{3}$ show a good correspondence (within the errors) in the liquid and the gelified electrolyte. The best agreement is found in the first time constant, corresponding to the cuprite layer, what indicates that the G-PE could be valid for the evaluation of the patinas on bronze.

Once the G-PE and liquid electrolytes were tested in the laboratory, a field-cell was fabricated (Fig. 1) and applied in a real bronze sculpture covered by a natural patina. The G-PE allows to easily carrying out measurements on different surfaces regardless of their orientation and position, and the flexibility of the G-PE allowed it to adapt itself to slightly curved or irregular surfaces which are commonly found on this type of artifacts.

Bode and Nyquistplots of the EIS spectrum obtained from the sculpture is shown in Figure 2 (b) and (d) respectively. Data have been fitted to the same equivalent circuit and results are shown in Table 1. This spectrum is presented to demonstrate the applicability of the G-PE cell to real objects and the good quality of the data that can be obtained. A detailed interpretation of the values of the circuit elements would require more EIS data and a deeper study of the bronze-patina system that is currently under development.

\section{Conclusions}

The gelification of a traditional liquid electrolyte using agar has demonstrated to be a convenient and practical system to fabricate an electrochemical cell for field EIS tests. The gelification does not produce a significant change in the properties of the electrolyte, allowing to obtain good quality EIS spectra. The gel-cell fabricated using this electrolyte allows to perform EIS tests in-situ in elements such as sculptures or monuments, expanding the possibilities for electrochemical characterization of metallic cultural heritage. Additionally, it 
can be applied to other systems that need in-situ application of electrochemical techniques for corrosion and protection assessment.

Acknowledgements: This work has been funded by project HAR2011-22402, Spanish Ministerio de Ciencia e Innovación, Plan Nacional de I+D+i 2008-2011. D. Lafuente expresses her gratitude to the CSIC and the European Social Fund for her JAE-Pre grant, and B. Ramirez to the Ministerio de Ciencia de Innovación for her FPI grant.

\section{References}

[1] E. Cano, D. Lafuente, D.M. Bastidas, Journal of Solid State Electrochemistry, 14 (2010) 381391.

[2] E. Cano, D.M. Bastidas, V. Argyropoulos, S. Fajardo, A. Siatou, J.M. Bastidas, C. Degrigny, Journal of Solid State Electrochemistry, 14 (2010) 453-463.

[3] R.d.P.B. Hernández, I.V. Aoki, B. Tribollet, H.G. de Melo, Electrochimica Acta, 56 (2011) 2801-2814.

[4] C. Chiavari, K. Rahmouni, H. Takenouti, S. Joiret, P. Vermaut, L. Robbiola, Electrochimica Acta, 52 (2007) 7760-7769.

[5] A. Doménech-Carbó, M.T. Doménech-Carbó, M.A. Peiró-Ronda, I. Martínez-Lázaro, J. Barrio-Martín, Journal of Solid State Electrochemistry, 16 (2012) 2349-2356.

[6] A. Doménech-Carbó, M. Lastras, F. Rodríguez, E. Cano, J. Piquero-Cilla, L. Osete-Cortina, Journal of Solid State Electrochemistry, (2013) 1-11.

[7] P. Letardi, Laboratory and field tests on patinas and protective coating systems for outdoor bronze monuments, in: J. Ashton, D. Hallam (Eds.) Metal 04. International Conference on Metal Conservation National Museum of Australia, Canberra (Australia), 2004, pp. 379-387. [8] P. Letardi, A. Beccaria, M. Marabelli, G. D'Ercoli, Application of electrochemical impedance mesurements as a tool for the characterization of the conservation and protection state of bronze works of art, in: J. Ashton, D. Hallam (Eds.) Metal 98. International Conference on Metal Conservation James \& James, Draguignan-Figanières (France), 1998, pp. 303-308.

[9] P. Letardi, R. Spiniello, Characterisation of bronze corrosion and protection by contactprobe electrochemical impedance measurements, in: I. MacLeod, J.M. Theile, C. Degrigny (Eds.) Metal 01. International Conference on Metal Conservation Western Australian Museum, Santiago (Chile), 2001, pp. 316-319.

[10] E. Angelini, S. Grassini, S. Corbellini, G.M. Ingo, T. De Caro, P. Plescia, C. Riccucci, A. Bianco, S. Agostini, Applied Physics A: Materials Science and Processing, 83 (2006) 643-649.

[11] E. Angelini, S. Grassini, M. Parvis, F. Zucchi, Surface and Interface Analysis, 44 (2012) 942946.

[12] S. Corbellini, M. Parvis, S. Grassini, IEEE Transactions on Instrumentation and Measurement, 61 (2012) 1193-1200.

[13] V. Di Noto, S. Lavina, G.A. Giffin, E. Negro, B. Scrosati, Electrochimica Acta, 57 (2011) 4-13.

[14] M.P. Vinod, K. Vijayamohanan, Journal of Power Sources, 89 (2000) 88-92.

[15] C.L. Cheng, C.C. Wan, Y.Y. Wang, Electrochemistry Communications, 6 (2004) 531-535.

[16] J.J. Xu, H. Ye, Electrochemistry Communications, 7 (2005) 829-835.

[17] E. Lima, E. Raphael, F. Sentanin, L.C. Rodrigues, R.A.S. Ferreira, L.D. Carlos, M.M. Silva, A. Pawlicka, Materials Science and Engineering: B, 177 (2012) 488-493.

[18] R. Leones, F. Sentanin, L.C. Rodrigues, I.M. Marrucho, J.M.S.S. Esperança, A. Pawlicka, M.M. Silva, Express Polymer Letters, 6 (2012) 1007-1016.

[19] J. Hassoun, F. Croce, C. Tizzani, B. Scrosati, Electrochemistry Communications, 9 (2007) 2045-2050. 
[20] S. Yamazaki, A. Takegawa, Y. Kaneko, J.-i. Kadokawa, M. Yamagata, M. Ishikawa, Electrochemistry Communications, 11 (2009) 68-70.

[21] S. Wu, T. Tsuruoka, K. Terabe, T. Hasegawa, J.P. Hill, K. Ariga, M. Aono, Advanced Functional Materials, 21 (2011) 93-99.

[22] H. An, B. Xue, D. Li, H. Li, Q. Meng, L. Guo, L. Chen, Electrochemistry Communications, 8 (2006) 170-172.

[23] M.F. Shukur, F.M. Ibrahim, N.A. Majid, R. Ithnin, M.F.Z. Kadir, Physica Scripta, 88 (2013). [24] A. Pawlicka, M. Danczuk, W. Wieczorek, E. Zygadło-Monikowska, Journal of Physical Chemistry A, 112 (2008) 8888-8895.

[25] R. Leones, F. Sentanin, L.C. Rodrigues, R.A.S. Ferreira, I.M. Marrucho, J.M.S.S. Esperança, A. Pawlicka, L.D. Carlos, M. Manuela Silva, Optical Materials, 35 (2012) 187-195.

[26] J.R. Andrade, E. Raphael, A. Pawlicka, Electrochimica Acta, 54 (2009) 6479-6483.

[27] C.J. Newton, J.M. Sykes, Corrosion Science, 28 (1988) 1051-1074.

[28] K. Marušić, H. Otmačić-Ćurković, S. Horvat-Kurbegović, H. Takenouti, E. Stupnišek-Lisac, Electrochimica Acta, 54 (2009) 7106-7113.

[29] H. Otmacic Curkovic, T. Kosec, K. Marušić, A. Legat, Electrochimica Acta, 83 (2012) 28-39.

[30] S.F. Patil, N.G. Adhyapak, The International Journal of Applied Radiation and Isotopes, 33 (1982) 105-108. 
Table 1.Parameters from the fitting of EIS spectra using the equivalent circuit in Fig. 2 (errors in parenthesis)

\begin{tabular}{|c|c|c|c|c|c|c|c|c|c|c|}
\hline \multirow[b]{2}{*}{ Specimen } & \multirow{2}{*}{$\begin{array}{c}\mathrm{R}_{\mathrm{e}} \\
\left(\Omega \mathrm{cm}^{2}\right)\end{array}$} & \multicolumn{2}{|c|}{$\mathrm{CPE}_{1}$} & \multirow{2}{*}{$\begin{array}{c}\mathrm{R}_{1} \\
\left(\Omega \mathrm{cm}^{2}\right)\end{array}$} & \multicolumn{2}{|c|}{$\mathrm{CPE}_{2}$} & \multirow{2}{*}{$\begin{array}{c}\mathrm{R}_{2} \\
\left(\Omega \mathrm{cm}^{2}\right)\end{array}$} & \multicolumn{2}{|l|}{$\mathrm{CPE}_{3}$} & \multirow{2}{*}{$\begin{array}{c}\mathrm{R}_{3} \\
\left(\Omega \mathrm{cm}^{2}\right)\end{array}$} \\
\hline & & $\begin{array}{c}\mathrm{Y}_{1} \\
\left(\mu \mathrm{S} \mathrm{s}^{\alpha_{1}} \mathrm{~cm}^{-2}\right)\end{array}$ & $\alpha_{1}$ & & $\begin{array}{c}Y_{2} \\
\left(\mathrm{mS} \mathrm{s}^{\alpha_{2}} \mathrm{~cm}^{-2}\right)\end{array}$ & $\alpha_{2}$ & & $\begin{array}{c}Y_{3} \\
\left(m S s^{\alpha_{3}} \mathrm{~cm}^{-2}\right)\end{array}$ & $\alpha_{3}$ & \\
\hline $\begin{array}{c}\text { Bronze } \\
\text { coupon/liquid } \\
\text { electrolyte }\end{array}$ & $\begin{array}{l}92.8 \\
( \pm 1)\end{array}$ & $\begin{array}{c}59 \\
( \pm 17)\end{array}$ & $\begin{array}{c}0.77 \\
( \pm 0.03)\end{array}$ & $\begin{array}{c}211 \\
( \pm 29)\end{array}$ & $\begin{array}{c}0.27 \\
( \pm 0.03)\end{array}$ & $\begin{array}{c}0.77 \\
( \pm 0.04)\end{array}$ & $\begin{array}{c}2608 \\
( \pm 390)\end{array}$ & $\begin{array}{c}1.7 \\
( \pm 0.4)\end{array}$ & $\begin{array}{c}0.77 \\
( \pm 0.11)\end{array}$ & $\begin{array}{l}10870 \\
( \pm 4500)\end{array}$ \\
\hline $\begin{array}{c}\text { Bronze } \\
\text { coupon/G-PE }\end{array}$ & $\begin{array}{l}103 \\
( \pm 2)\end{array}$ & $\begin{array}{c}44 \\
( \pm 20)\end{array}$ & $\begin{array}{c}0.76 \\
( \pm 0.06)\end{array}$ & $\begin{array}{c}254 \\
( \pm 121)\end{array}$ & $\begin{array}{c}0.12 \\
( \pm 0.03)\end{array}$ & $\begin{array}{c}0.64 \\
( \pm 0.04)\end{array}$ & $\begin{array}{c}4667 \\
( \pm 504)\end{array}$ & $\begin{array}{c}5.0 \\
( \pm 3.8)\end{array}$ & $\begin{array}{c}0.83 \\
( \pm 0.29)\end{array}$ & $\begin{array}{c}5264 \\
( \pm 2623)\end{array}$ \\
\hline $\begin{array}{c}\text { Bronze } \\
\text { sculpture/G-PE }\end{array}$ & $\begin{array}{c}30 \\
( \pm 0.3)\end{array}$ & $\begin{array}{l}239 \\
( \pm 21)\end{array}$ & $\begin{array}{l}0.75 \\
( \pm 14)\end{array}$ & $\begin{array}{c}551 \\
( \pm 82)\end{array}$ & $\begin{array}{c}1.40 \\
( \pm 0.30)\end{array}$ & $\begin{array}{c}0.73 \\
( \pm 0.02)\end{array}$ & $\begin{array}{c}884 \\
( \pm 323)\end{array}$ & $\begin{array}{l}8.7 \\
( \pm 8)\end{array}$ & $\begin{array}{c}0.87 \\
(0.12)\end{array}$ & $\begin{array}{c}1470 \\
( \pm 1000)\end{array}$ \\
\hline
\end{tabular}


Figure 1:Scheme and photograph of the gel polymer electrolyte cell.
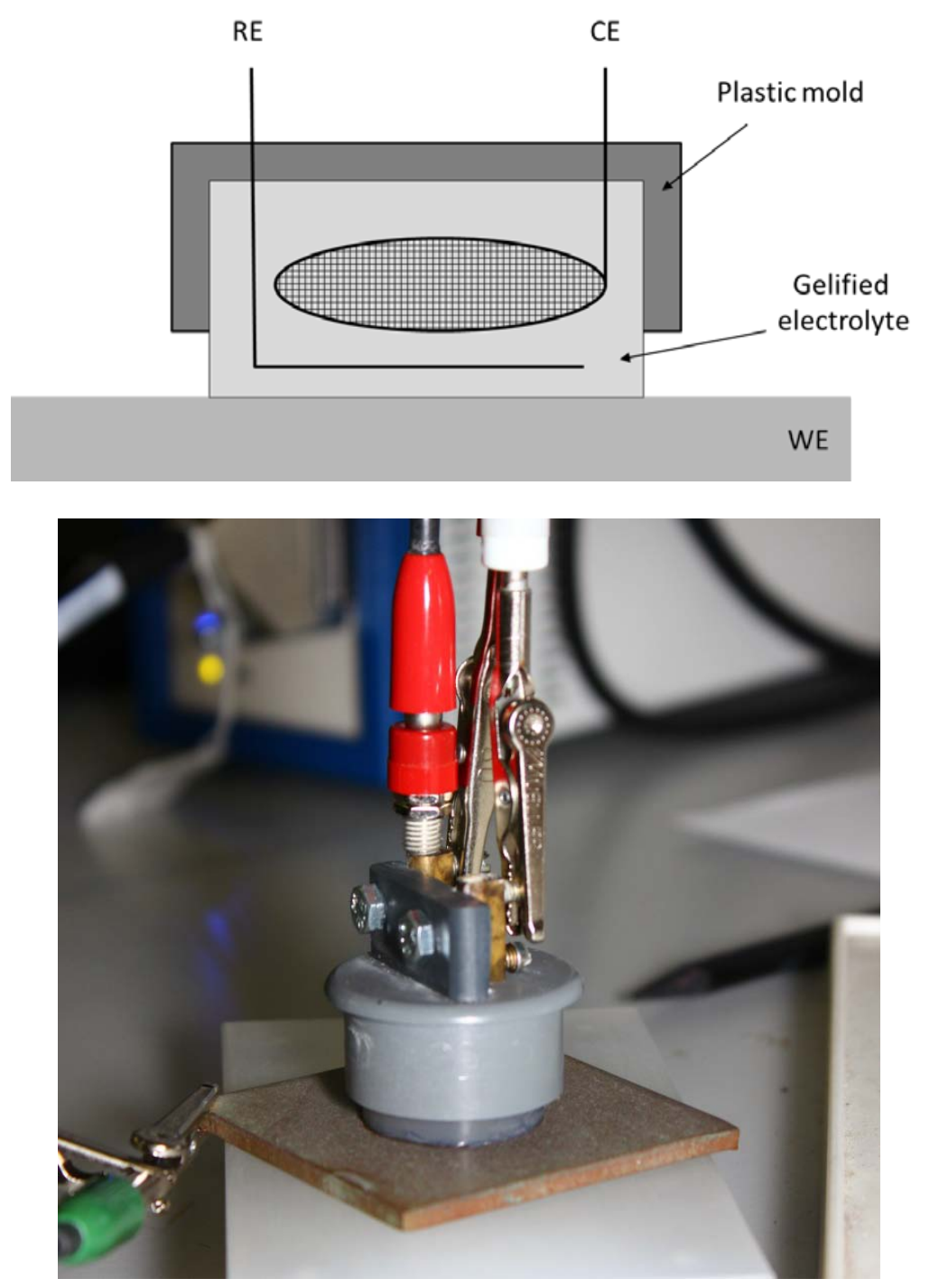
Figure 2: Typical EIS spectra obtained for the different samples: Bode (a) and Nyquist (c) plots of bronze coupons using the liquid electrolyte and the G-PE; and Bode (b) and Nyquist (d) plots of the bronze sculpture using the GP-E. Hollow figures represent experimental data and crosses (+) the results of the fitting.
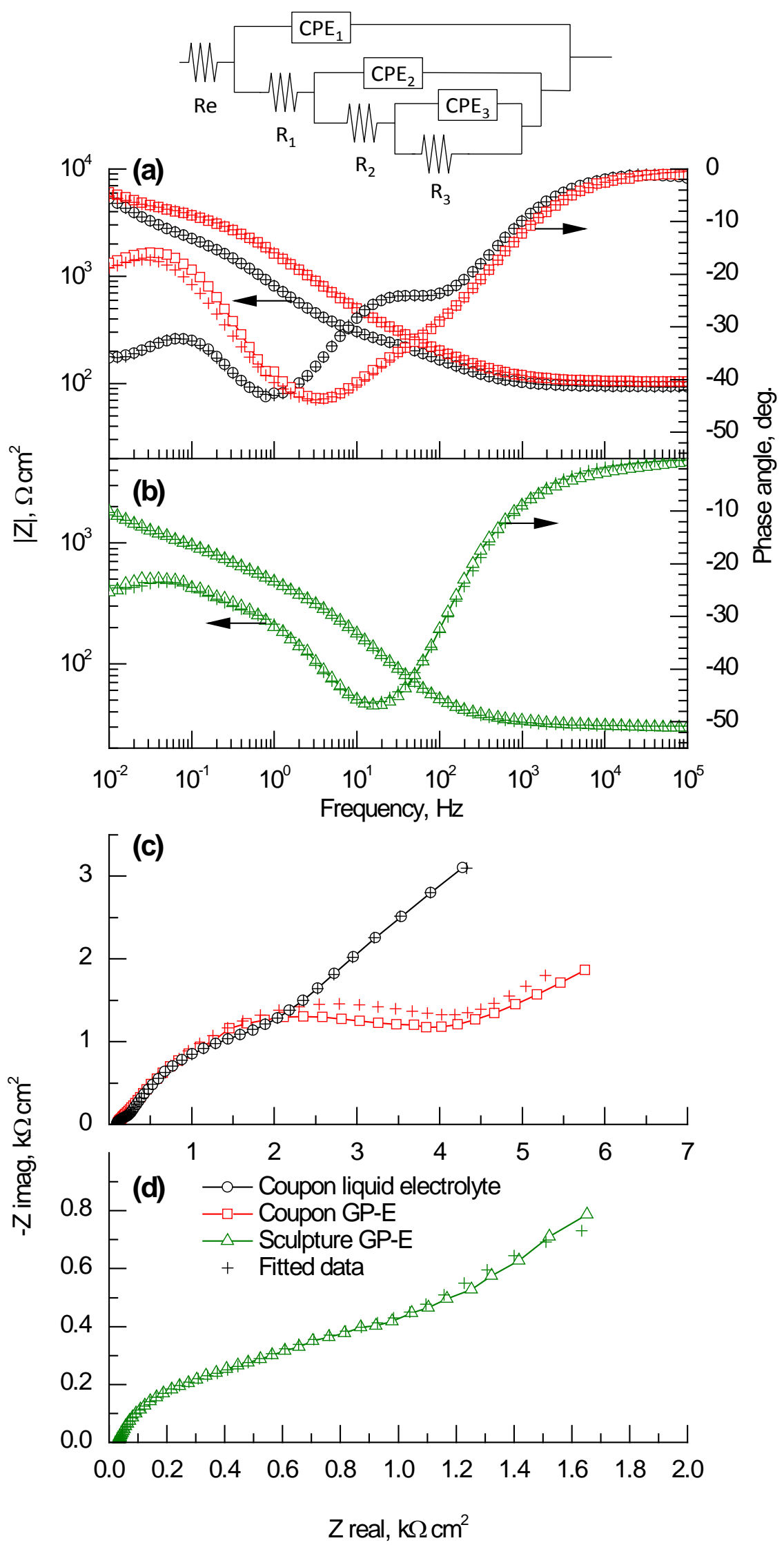